2. Hackel, D.B., Reimer, K.A., Ideker, R.E. et al. Comparison of enzymatic and anatomic estimates of myocardial infarct size in man. Circulation 1984, 70: 824-835.

3. Ogawa, H., Hiramori, K., Haze, K. et al. Comparison of clinical features of non- $Q$ wave and $Q$ wave myocardial infarction. Am Heart J 1986, 111: 513-518.

4. Wei, J.Y., Markis, J.E., Malagold, M. \& Grossman, W. Time course of serum cardiac enzymes after intracoronary thrombolytic therapy. Arch Intern Med 1985, 145: 1596-1600.

\section{Mediastinal germ cell tumour and myelodysplastic syndrome}

Sir,

Nichols et al. ${ }^{1}$ have recently described 16 cases of haematological neoplasia associated with non-seminomatous mediastinal germ cell tumours and suggest that these neoplasms may arise from a common progenitor cell.

We wish to report a 20 year old man with an enormous primary mediastinal germ cell tumour with histological evidence of yolk-sac elements in combination with teratoma, and high alpha-fetoprotein (AFP) serum levels $(2130 \mathrm{ng} / \mathrm{ml})$. He was treated with six courses sequentially of combinations of cisplatin, etoposide, ifosfamide and bleomycin with a partial response as measured by thoracic scan and the reduction of AFP levels to $190 \mathrm{ng} / \mathrm{ml}$.

During the chemotherapy treatment, the patient developed persistent pancytopenia and a severe myelodysplastic syndrome with abnormal megakaryocytes in two bone marrow biopsies. The cytogenetic analysis demonstrated three abnormal clones: trisomy 1 with an extra marker chromosome, a second clone with, added to the first, a trisomy 18 and a third clone with an extra 8 chromosome. The karyotype yielded $48, \mathrm{XY},+1,+\operatorname{mar} / 49, \mathrm{XY}$, $+1,+18,+\operatorname{mar} / 50, \mathrm{XY},+1,+8,+18,+\operatorname{mar}$.

In the patients who develop a chemotherapy or radiotherapy related leukaemia or myelodysplastic syndrome, the karyotype usually shows a hypodiploid modal number and abnormalities in chromosomes 3, 5, 7 and $17 .^{2}$ However, in this patient's karyotype the deletions and monosomies often found in people with therapy related haematological neoplasms were not present. On the other hand, trisomy 8 , frequently observed in myelodysplastic syndromes, ${ }^{3}$ was found.

We feel that this young man with non-seminomatous primary mediastinal germ cell tumour and severe myelodysplastic syndrome with cytogenic abnormalities beginning after chemotherapy treatment, is similar to those patients reported by Nichols et al.'

M. Serrano, J.L. Rodríguez-García,

T. Ferro,

G. Fraile,

J.G. Laraña ${ }^{2}$

Departments of Internal Medicine,

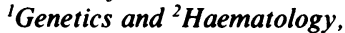

Hospital Ramón y Cajal,

Madrid, Spain.
References

1. Nichols, C.R., Roth, B.J., Heerema, Griep, J. \& Tricot, G. Hematologic neoplasia associated with primary mediastinal germ-cell tumors. $N$ Engl J Med 1990, 322: 1425-1429.

2. Groupe Francais de Cytogenetique Hematologique. Chromosome analysis of 63 cases of secondary non-lymphoid blood disorders: a cooperative study. Cancer Genet Cytogenet 1984, 12: 95-104.

3. Musilova, J. \& Michalova, K. Chromosome study of 85 patients with myelodysplastic syndrome. Cancer Genet Cytogenet 1988, 33: 39-50.

\section{Doxycycline-induced parotitis}

Sir,

Sialadenitis is an uncommon side effect of drugs and chemicals such as nifedipine, ${ }^{1,2}$ alpha-methyldopa, ${ }^{3}$ phenylbutazone, ${ }^{4}$ interferon alpha, ${ }^{5}$ H2 receptor antagonists, ${ }^{6}$ oxyphenbutazone, ${ }^{7}$ iodine compounds ${ }^{8}$ and nitrofurantoin. ${ }^{9}$ To our knowledge, no cases of doxycycline-induced sialadenitis have been described until now.

An 18 year old female developed serum sickness while receiving doxycycline for inflammatory acne. She had been taking doxycycline $200 \mathrm{mg} /$ day orally for 15 days when she voluntarily discontinued the treatment for 1 week. Forty eight hours after reintroducing this drug, she developed fever $\left(38.2^{\circ} \mathrm{C}\right)$, chills, generalized urticaria, hand and foot oedema, and arthralgia in both knees, ankles and wrists. She had not received any other medication during the previous 3 months. Physical examination also revealed bilateral cervical lymphadenopathy up to $2 \mathrm{~cm}$ in diameter. Seventy-two hours later, she developed bilateral painful parotid swelling. There was tenderness, reddening and an increased temperature of the skin over the glands. Simultaneously, a recrudescence of urticarial lesions was observed. Other studies showed mild leukocytosis $(12,700 / \mathrm{mm})$, elevated ESR (52 $\mathrm{mm}$ in the first hour), hypocomplementaemia $(\mathrm{C} 4,10 \mathrm{mg} / \mathrm{dl})$ and proteinuria $(1.6 \mathrm{~g} / \mathrm{l})$ and haematuria ( 33 red cells per high power field). Serum protein electrophoresis and serum immunoglobulins were within normal limits. Antinuclear antibodies and hepatitis B surface antigen were not detected in serum. She was treated with methylprednisolone $80 \mathrm{mg}$ daily intravenously and hydroxyzine $100 \mathrm{mg} /$ day orally. The parotitis resolved in 24 hours and the rest of the clinical manifestations in 5 days.

The mechanism of drug-induced sialadenitis remains unclear in most cases. Either oedema and spasm of smooth muscle in the salivary gland or a hypersensitivity reaction could be responsible. ${ }^{1,3,5-7,9}$ In the case reported here, the association between serum sickness and parotitis during doxycycline therapy points to an immunological pathogenesis.

Carmen Vidal Pan Arturo González Quintela' Departments of Allergy and 'Internal Medicine, Hospital Puerta de Hierro, c) San Martín de Porres 4, 28035 Madrid, Spain. 


\section{References}

1. Bosch, X., Campistol, J.M., Botey, A., Cases, A. \& Revert, L. Nifedipine-induced parotitis (Letter to the Editor). Lancet, 1986, 23: 467.

2. Massimo, C., Sebastianelli, G. \& Noera, G. Nifedipineinduced parotitis: a hypersensitivity reaction (Letter to the Editor). Am J Cardiol 1988, 61 (Suppl): 874.

3. Mårdh, P.A., Belfrage, I. \& Naversten, E. Sialadenitis following treatment with $\alpha$-methyldopa. Acta Med Scand 1974, 195: 333-335.

4. Mirsky, S. Salivary gland reaction to phenylbutazone. Can Med Assoc J 1970, 102: 91.

5. Bevan, P.C. Interferon-induced parotitis and epididymitis (Letter to the Editor). Lancet 1985, ii: 561.

6. Tomasko, M.A. \& Luskin, A.T. Recurrent parotitis with $\mathrm{H} 2$ receptor antagonists in a patient with Sjögren syndrome. Am J Med 1988, 85: 271.

7. Chen, J.H., Ottolenghi, P. \& Distenfeld, A. Oxyphenbutazoneinduced sialadenitis. JAMA 1977, 238: 1399.

8. Harden, R. Submandibular adenitis due to iodine administration. Br Med J 1968, 1: 160-161.

9. Pellinen, T. \& Kalske, J. Nitrofurantoin-induced parotitis. $B r$ Med J 1982, 285: 344.

\section{Crohn's disease in the elderly}

Sir,

When faced with the symptoms of altered bowel habit and weight loss in an elderly patient, malignant disease is usually suspected. It is, however, always worth considering Crohn's disease, as the following case illustrates.

A frail 80 year old woman presented with a 2 month history of constipation, rectal bleeding and weight loss of $1 \mathrm{~kg}$. Her haemoglobin was $10 \mathrm{~g} / \mathrm{dl}$ and both erythrocyte sedimentation rate (ESR) and acute phase proteins (C-reactive protein and alpha-1-acid glycoprotein) were raised. Barium enema showed gross deformity of the rectosigmoid region typical of diverticular disease along with an adjacent area of mucosal irregularity raising the possibility of co-existent malignancy - biopsies taken at flexible sigmoidoscopy however revealed active Crohn's disease at this site.

In view of her general condition, further gastrointes tinal investigations were not performed. She was treated. with sulphasalazine $3 \mathrm{~g}$ daily and Colifoam enemas. $A \vec{F}$ review one month later her bowel habit was normal, her? ESR had fallen, and she had gained $2 \mathrm{~kg}$ in weight.

This case illustrates the unexpected finding of colonic Crohn's disease during the investigation of an elderly patient suspected of having malignant disease. Crohn's disease in the elderly predominantly affects females, favours the recto-sigmoid junction, ${ }^{2}$ and is most com-s monly misdiagnosed as diverticular disease. ${ }^{3}$ Colonic $\overrightarrow{0}$ disease usually responds well to medical therapy with $a-$ low recurrence rate. ${ }^{4}$

Both general physicians and geriatricians should be alert to the possibility of Crohn's disease in their elderlyo patients presenting with weight loss and bowel disturb 3 . ance.

I. Gillanders@ B. Daneshicu

Gastroenterology Unit, $\vec{\omega}$ Stobhill General Hospital, ف่ Balornock Road,o Glasgow G21 3UW, UK

\section{References}

1. Stalnikowicz, R., Eliakim, R., Diab, R. \& Rachmilewitz, \$ٔ. Crohn's disease in the elderly. J Clin Gastroenterol 1989, 1 411-415.

2. Carr, N. \& Schofield, P.F. Inflammatory bowel disease in older patient. Br J Surg 1982, 69: 223-225.

3. Foxworthy, D.M. \& Wilson, J.A.P. Crohn's disease in the elderly - prolonged delay in diagnosis. J Am Geriatr Soc 1985, 33: 492-495.

4. Fabricius, P.J., Gyde, S.N., Shouler, P., Keighley, M.R.B., Alexander-Williams, J. \& Allan, R.N. Crohn's disease in the elderly. Gut 1985, 26: 461-465. 